\title{
Struktur Sel Sekresi Daun Jeruk Kalamansi (Citrus microcarpa Bunge.) di Pulau Ambon
}

\section{Secretory Cell Structure on the Leaf of Calamansy Lime (Citrus microcarpa Bunge.) in Ambon Island}

\author{
Christina Horowidi $^{1}$, Hermalina Sinay ${ }^{1 *}$, Ritha Lusian Karuwal ${ }^{1}$, Lona Parinussa ${ }^{2}$ \\ ${ }^{1}$ Program Studi Pendidikan Biologi, Fakultas Keguruan dan Ilmu Pendidikan, Universitas Pattimura \\ Jl. Ir. M. Putuhena, Ambon 97233, Indonesia \\ ${ }^{2}$ Sekolah Menengah Pertama Negeri 9 Ambon \\ Jl. Wolter Monginsidi, Lateri, Ambon 97231, Indonesia \\ *Email: elinasinay08@gmail.com
}

Diterima 6 Agustus 2021 / Disetujui 8 September 2021

\begin{abstract}
ABSTRAK
Perbedaan lokasi tumbuh dapat mengakibatkan perbedaan penampilan fenotipik tanaman yang dapat diamati secara morfologi dan anatomi seperti struktur anatomi sel sekretori. Tujuan penelitian ini adalah untuk mengetahui struktur sel sekretori daun jeruk kalamansi di pulau Ambon. Metode jelajah dilakukan pada 13 lokasi di Pulau Ambon untuk koleksi sampel, dan pada setiap lokasi diambil 3 tanaman sebagai 3 ulangan. Tiap tanaman diambil 5 daun pada setiap sisi pohon tanaman jeruk kalamansi dengan ukuran panjang 5-7 cm dan warna hijau tua. Pembuatan preparat mengikuti metode free hand section. Pengamatan menggunakan kamera Optilab pada mikroskop Olympus dengan perbesaran 400x. Pengukuran diameter sel menggunakan fitur measure pada software Image Ruster. Data kualitatif berupa struktur sel sekresi daun jeruk Kalamansi ditampilkan dalam bentuk gambar dan dideskripsikan sesuai hasil yang terlihat, sedangkan data hasil pengukuran diameter sel sekresi adalah rerata 3 ulangan dan ditampilkan sebagai mean \pm standar deviasi (SD). Hasil penelitian menunjukkan adanya sel sekretori yang berjumlah satu sel. Struktur sel sekretori terdiri dari sel epitel, sel selubung, dan rongga sekretori. Bentuk sel sekresi ada yang bulat dan lonjong. Diameter rongga sekretori berkisar antara 106,08-167,60 $\mu \mathrm{m}$. Berdasarkan hasil penelitian, maka dapat disimpulkan bahwa sel sekresi pada daun jeruk kalamansi pada lokasi-lokasi berbeda di Pulau Ambon bervariasi baik bentuk maupun ukurannya.
\end{abstract}

Kata kunci: bentuk, ukuran, sel sekresi, jeruk kalamansi

\begin{abstract}
Differences in habitat can induce differences in the phenotypic appearance of plants that can be observed morphologically and anatomically such as the anatomical structure of secretory cells. The purpose of this study was to determine the structure of the secretory cells in the leaves of Calamansy citrus in Ambon island. Tracking method was done for sample collections, and at each location 3 plants were taken as replicates. Each plant was taken 5 leaves with a length of $5-7 \mathrm{~cm}$ and dark green color. Prior to be observed, the fresh sample was done with free-hand section method. Microscopy observations were done by a light microscope at 400x magnification. Measurement of cell diameter was done by the measure feature in Image Ruster software. Qualitative data such as secretory cell structures of Calamansy citrus leaves were shown in form of images and described according to the results, while the data of the measurement of secretory cell diameters is the average of 3 replications and was shown as mean \pm standard deviation (SD). The results showed the presence of secretory cells which amounted to one cell. The secretory cell structure is composed of epithelial cells, sheath cells, and secretory cavities. Cell shapes vary, including round and oval. The diameter of the secretory cell cavity ranges from $106.08-167.60 \mu \mathrm{m}$.
\end{abstract}

Keywords: form, shape, secretory cell, Calamansi citrus 


\section{PENDAHULUAN}

Keanekaragaman hayati Indonesia khususnya tumbuh-tumbuhan memiliki nilai penting baik sebagai sumber pangan, maupun obatobatan sehingga layak untuk dikembangkan. Salah satu komoditas hortikultura yang menjadi unggulan Indonesia adalah buah-buahan (Rahayu dan Susanto, 2012). Di antara sekian banyak buahbuahan yang ada di Indonesia, jeruk merupakan salah satu komoditas yang menjadi buah andalan Nasional Indonesia (Fikrinda, 2012), dan menjadi salah satu sumber daya genetik dengan keragaman tinggi (Yulianti dkk, 2016). Tingginya keragaman genetik jeruk ditunjukkan dengan beragamnya aksesi jeruk yang terdapat pada koleksi Balai Penelitian Jeruk dan Buah Tropika (Balitjestro) yaitu sekitar 254 aksesi (Balitjestro, 2019).

Menurut Balitjestro (2019), jenis jeruk yang dibudidayakan di Indonesia saat ini adalah jeruk nipis (C. aurantifolia), jeruk pamelo (C. grandis), jeruk purut $(C$. hystrix), jeruk manis $(C$. sinensis), jeruk lemon ( $C$. medica), jeruk keprok $(C$. reticulata), jeruk besar (C. maxima), jeruk siam $(C$. suhuiensis), nagami/kumquat (Fortunella margarita), dan juga jeruk-jeruk hasil persilangan seperti Tangelo (C. reticulata $\mathrm{x} C$. maxima), Tangor (C. reticulata $\mathrm{x} \quad C$. sinensis) Citrumello (P.trifoliata $x \quad C$. maxima), dan Citrange (P.trifoliata x C. sinensis). Selain jenis-jenis jeruk yang telah dikoleksi oleh Balitjestro, masih terdapat jenis-jenis jeruk lokal pada banyak wilayah di Indonesia yang dibudidayakan dan dikonsumsi oleh masyarakat. Salah satu jenis jeruk yang sudah sangat popular dan dikonsumsi oleh masyarakat di Ambon dan Maluku yaitu jeruk Kalamansi (C. microcarpa Bunge.) Jeruk Kalamansi diduga merupakan native plant dari Filipina (Wu et al., 2018), dan sudah dikenal di negara lain di Asia Tenggara (Rini 2018), bahkan dalam standar produksi dan pemasaran jeruk di ASEAN secara spesifik memuat aturan produksi, pengemasan dan pemasaran jeruk Kalamansi atau Calamansi Lime (ASEAN Standart, 2019).

Kehadiran jeruk Kalamansi (C. microcarpa Bunge.) kurang popular di Indonesia. Sebelum tahun 2000-an, jeruk ini hanya populer di Maluku, dan Manado dengan nama daerah lemon cina (Maluku) dan lemon cui (Manado). Baru beberapa tahun belakangan ini, jeruk Kalamansi ( $C$. microcarpa Bunge.) mulai terlihat dijual dalam bentuk anakan di sentra-sentra penjualan anakan tanaman hias. Itupun sepertinya hasil cangkokan yang bukan berasal dari biji, dan juga dalam jumlah yang terbatas, dan hanya dipelihara sebagai tanaman hias atau tanaman buah dalam pot (tabulampot). Di pasar tradisional atau di swalayanswalayan di kota-kota besar di Indonesia tidak pernah ditemukan adanya jeruk Kalamansi $(C$. microcarpa Bunge.) pada counter-counter buahbuahan khusus jeruk. Hal ini sangat bertolak belakang dengan kehadiran dan kepopuleran jeruk Kalamansi (C. microcarpa Bunge.) di Maluku.

Masyarakat Maluku hampir di semua wilayah Desa, kelurahan, kecamatan, dan kabupaten/kota mengenal dan sangat familiar dengan jeruk Kalamansi ini, namun dengan nama lokal lemon cina. Istilah Kalamansi adalah istilah asing yang berasal dari bahasa Tagalog di Filipina kalaman-śi yang diIndonesiakan menjadi Kalamansi (Inggris Calamansi) dan di Malaysia disebut juga jeruk kasturi (Surlitah dkk, 2015). Di Maluku bahkan kepopuleran dan pemanfaatan jeruk Kalamansi melebihi jeruk nipis. Kepopuleran jeruk Kalamansi di Ambon menjadi saingan jeruk nipis, karena aroma yang sangat khas dan juga rasa yang sangat asam. Selain di Ambon dan Maluku secara umum, jeruk Kalamansi juga dikenal di Papua dan Manado karena kebiasaan masyarakat di daerahdaerah ini yang selalu mengkonsumsi makanan laut. Rasa asam dan aroma yang khas diyakini dapat memberikan cita rasa yang sangat sesuai terhadap olahan makanan berupa hasil-hasil laut tersebut.

Pada banyak desa dan kelurahan di wilayah Pulau Ambon, jeruk Kalamansi dapat ditemukan dengan mudah di area pemukiman warga seperti di samping rumah, di halaman, atau di pinggiran jalan, di daerah dataran rendah maupun daerah pegunungan. Dengan beragamnya tempat tumbuh jeruk, menunjukkan bahwa jeruk ini memiliki kemampuan adaptasi yang luas terhadap habitat yang berbeda-beda. Respon tanaman terhadap faktor lingkungan terlihat pada penampilan tanaman. Jika faktor lingkungan tidak mendukung, maka tanaman berusaha menanggapi kebutuhan 
khususnya selama siklus hidupnya.Tanggapan ini dapat berupa morfologis, fisiologis, dan anatomis. Menurut Haryanti (2010) tanaman yang memiliki genotip yang sama, jika tumbuh dalam lingkungan yang berbeda, maka penampilan tanaman dapat berbeda pula.

Kajian tentang jenis-jenis sel sekresi berbeda-beda pada jenis-jenis tumbuhan, karena bentuk dan tipe sel sekresi serta sekret yang dikeluarkan oleh jenis tumbuhan juga berbedabeda. Spesies jeruk termasuk jeruk Kalamansi juga merupakan salah satu tumbuhan yang memiliki sel sekresi pada daunnya. Struktur sel yang menyusun jaringan sekresi ini perlu diteliti terutama pada jeruk Kalamansi yang tumbuh pada kondisi lingkungan yang beragam seperti di daerah Pulau Ambon. Berdasarkan uraian latar belakang ini, maka tujuan penelitian ini adalah untuk mengetahui struktur sel sekresi pada daun jeruk Kalamansi di Pulau Ambon.

\section{METODE PENELITIAN}

Penelitian ini menggunakan metode jelajah/tracking untuk menemukan tumbuhan jeruk pada 13 Desa sebagai lokasi penelitian, sedangkan teknik pengambilan sampel yaitu secara accidental sampling dan purposive sampling.

Pemilihan tanaman, pada satu lokasi diambil 3 tanaman dan dianggap sebagai 3 ulangan. Pada satu tanaman diambil 5 daun pada bagian pangkal (panjang $\pm 5-7 \mathrm{~cm}$ ) yang berwarna hijau tua. Sampel daun kemudian dimasukkan dalam alkohol $70 \%$ dan dibawa ke laboratorium untuk diamati.

Pembuatan preparat, mengikuti metode freehand section (Sinay et al. 2015; Rahangmetan dkk, 2021). Daun yang diambil dari setiap lokasi dipotong dengan ukuran $0,5 \times 1 \mathrm{~cm}$, dimasukkan ke dalam alkohol $70 \%$ dan disimpan untuk dibuat preparat semi permanen. Potongan daun diambil dari dalam alkohol $70 \%$, kemudian dibuat sayatansayatan tipis melintang dengan cara memasukan potongan daun ke dalam belahan wortel, kemudian disayat menggunakan silet tajam. Sayatan tipis dibuat sebanyak-banyaknya dan dipilih sayatan yang paling tipis kemudian diletakkan di atas kaca objek yang sudah ditetesi gliserin, ditutup dengan gelas penutup dan diletakkan di bawah mikroskop untuk diamati.

Pengamatan, dilakukan dengan pembesaran 400x menggunakan kamera Optilab pada mikroskop Olympus yang sudah terkoneksi dengan Komputer. Variabel yang diamati yaitu bentuk dan ukuran diameter sel sekresi. Pengukuran dimeter sel sekresi menggunakan fitur measure pada Software Image Ruster®.

Analisis data, dilakukan secara deskriftif. Data kualitatif berupa struktur sel sekresi daun jeruk Kalamansi ditampilkan dalam bentuk gambar, sedangkan data hasil pengukuran diameter sel sekresi adalah rerata 3 ulangan dan ditampilkan sebagai mean \pm standar deviasi (SD).

\section{HASIL DAN PEMBAHASAN}

Jeruk Kalamansi (C. microcarpa Bunge.) adalah jeruk dengan rasa yang masam. Di Maluku termasuk di Ambon, jeruk ini sangat populer dan selalu digunakan dalam setiap masakan khas Ambon/Maluku untuk memberikan cita rasa asam pada makanan. Jeruk Kalamansi memiliki bau yang sangat harum menyengat yang menjadi ciri khasnya. Menurut Fajarsari (2017) bahwa adanya aroma atau bau yang khas pada jeruk berasal dari minyak atsiri yang terdapat pada kulit buah dan daun jeruk. Diketahui bahwa minyak atsiri adalah salah satu senyawa metabolit sekunder yang dihasilkan oleh sel-sel sekresi. Nindyawati dan Indriyani (2017) menyatakan bahwa sel sekresi merupakan struktur sekresi khusus yang mensekresikan senyawa-senyawa tertentu yang tidak dikeluarkan dari tubuh tumbuhan. Lokasi pengambilan sampel yaitu 13 Desa di Pulau Ambon yakni: Desa Halong, Hatiwe Besar, Hukurila, Hutumuri, Kilang, Kusu-Kusu Sereh, Latta, Lateri, Naku, Passo, Poka, Rumahtiga dan Wayame. Hasil pengamatan sayatan melintang daun jeruk Kalamansi menunjukkan adanya sel sekresi (Gambar 1 sampai dengan Gambar 3).

Struktur sel sekresi terdiri dari sel seludang (ss), sel epitel (se) dan rongga sekretori (rs)/cavity. Sel seludang adalah lapisan paling luar, yang terdiri dari satu atau beberapa lapisan sel yang saling bersambungan berbentuk seperti lingkaran yang mengelilingi sel epitel, sedangkan sel epitel berada 
di sebelah dalam yang membatasi ruang/rongga sekretori (Gambar 1-3). Sel seludang tidak memiliki batas yang jelas, tetapi lebih kelihatan seperti lapisan memadat berbentuk lingkaran atau oval sesuai dengan bentuk sel sekretorinya, dan membatasi rongga sekretori dengan sel-sel di sekitarnya (Turner \& Lange 2015). Fajarsari (2017) menyatakan bahwa sel seludang dan sel epitel ini dapat mengalami robekan atau pecah sebagai jalan untuk masuknya sekret ke dalam rongga sekresi tersebut. Hidayat (1995) menyatakan bahwa ruang atau rongga (cavity) sekretori pada jeruk (Citrus $s p$ ) terbentuk secara lisigen yaitu dengan lisis atau larutnya sel-sel parenkim sehingga menjadi suatu rongga, sedangkan menurut Nugroho (2017), sel sekretori pada daun jeruk terbentuk secara lisigen dan berisi minyak, sehingga disebut sebagai sel-sel minyak/kelenjar minyak (oil gland).

Menurut Fajarsari (2017) sel sekresi ini terbentuk dari sel-sel parenkim yang mengalami diferensiasi. Hal ini sesuai dengan gambar hasil pengamatan yang menunjukkan bahwa sel sekresi berada pada bagian daun yaitu mesofil, di mana pada bagian ini terdapat jaringan parenkim yaitu parenkim tiang (parenkim palisade) dan parenkim bunga karang (parenkim spons). Sesuai dengan gambar, dapat dilihat dengan jelas bahwa sel sekresi berada di sekitar sel-sel parenkim tiang maupun parenkim spons dan sel sekresi memiliki bentuk yang sangat berbeda dengan sel-sel parenkim di sekitarnya. Diferensiasi parenkim ini bertujuan untuk menyesuaikan dengan fungsi selnya yaitu sebagai penimbun sekret dalam hal ini senyawa yang dikeluarkan oleh tumbuhan dan tidak dibuang ke luar tubuh, tetapi disimpan di dalam sel yaitu sel sekresi (khususnya pada daun jeruk yaitu senyawa berupa minyak). Sel sekresi seperti ini disebut sel sekresi internal, karena menampung sekret yang tidak dikeluarkan dari tubuh tumbuhan. Menurut Dorly dkk, (2015) Struktur sekresi dibedakan menjadi dua berdasarkan lokasinya yaitu struktur sekresi eksternal meliputi trikoma, nektarium atau kelenjar madu, hidatoda serta stigma dan struktur sekresi internal berupa idioblas, rongga sekresi, saluran sekresi dan latisifer.

Umumnya jumlah sel sekresi pada setiap bidang pandang dari satu potongan daun yang diamati adalah satu sel. Variasi pada struktur sel sekresi nampak pada bentuk dan ukurannya. Jika diamati, bentuk sel sekresi berbeda-beda. Ada yang berbentuk bulat, dan ada yang berbentuk oval. Selain variasi pada bentuk, sel sekresi pada daun jeruk Kalamansi juga bervariasi dalam ukuran diameter rongga sekretorinya (Tabel 3).

Ukuran rongga sekretori daun jeruk Kalamansi di beberapa lokasi di Pulau Ambon bervariasi, dan berkisar antara 106,08 $\mu \mathrm{m}$ sampai $167,60 \mu \mathrm{m}$ dengan rata-rata $126,92 \mu \mathrm{m}$. Variasi ukuran diameter rongga sekretori pada tumbuhan jeruk Kalamansi menunjukkan bahwa setiap individu tumbuhan memiliki perbedaan dalam perkembangan selulernya. Menurut Bennici dan Tani (2004) pada Citrus, ontogeni sel sekresi secara berurutan terdiri dari pemisahan dinding sel disertai dengan disorganisasi struktural dari sitoplasma, hilangnya inti sel, plasmolisis, dan diikuti oleh proses autolisis. Diduga, bahwa besar atau kecilnya ukuran diameter rongga sekretori lebih berkaitan dengan cepat atau lambatnya sel-sel yang mengalami lisis. Selain itu dinyatakan pula bahwa ukuran sel minyak bertambah besar karena adanya pertumbuhan dan penggabungan satu atau lebih vakuola secara lisigen, skisogen atau gabungan keduanya yang saling tumpang tindih. Ukuran besar kecilnya rongga sekretori ini akan berfungsi untuk menampun sekret yang dikeluarkan oleh tumbuhan.

Fahn (1988) menyatakan bahwa ontogeni sel-sel sekresi pada tumbuhan dapat dipengaruhi oleh faktor eksternal seperti infeksi patogen. Pada jeruk, pembentukan saluran getah (gummosis) dapat terjadi sebagai respon terhadap infeksi jamur dan virus. Namun demikian, perbedaan dalam ukuran rongga sekretori yang dipengaruhi oleh lingkungan eksternal seperti infeksi patogen belum banyak dilaporkan. Jian-Liang et al. (2006) menyatakan bahwa jenis perkembangan rongga sekretori pada genus Citrus sampai saat ini masih kontroversial, dan hubungan antara perkembangan rongga sekretori dan akumulasi minyak atsiri dalam buah-buahan seperti Citrus juga belum banyak diketahui. 

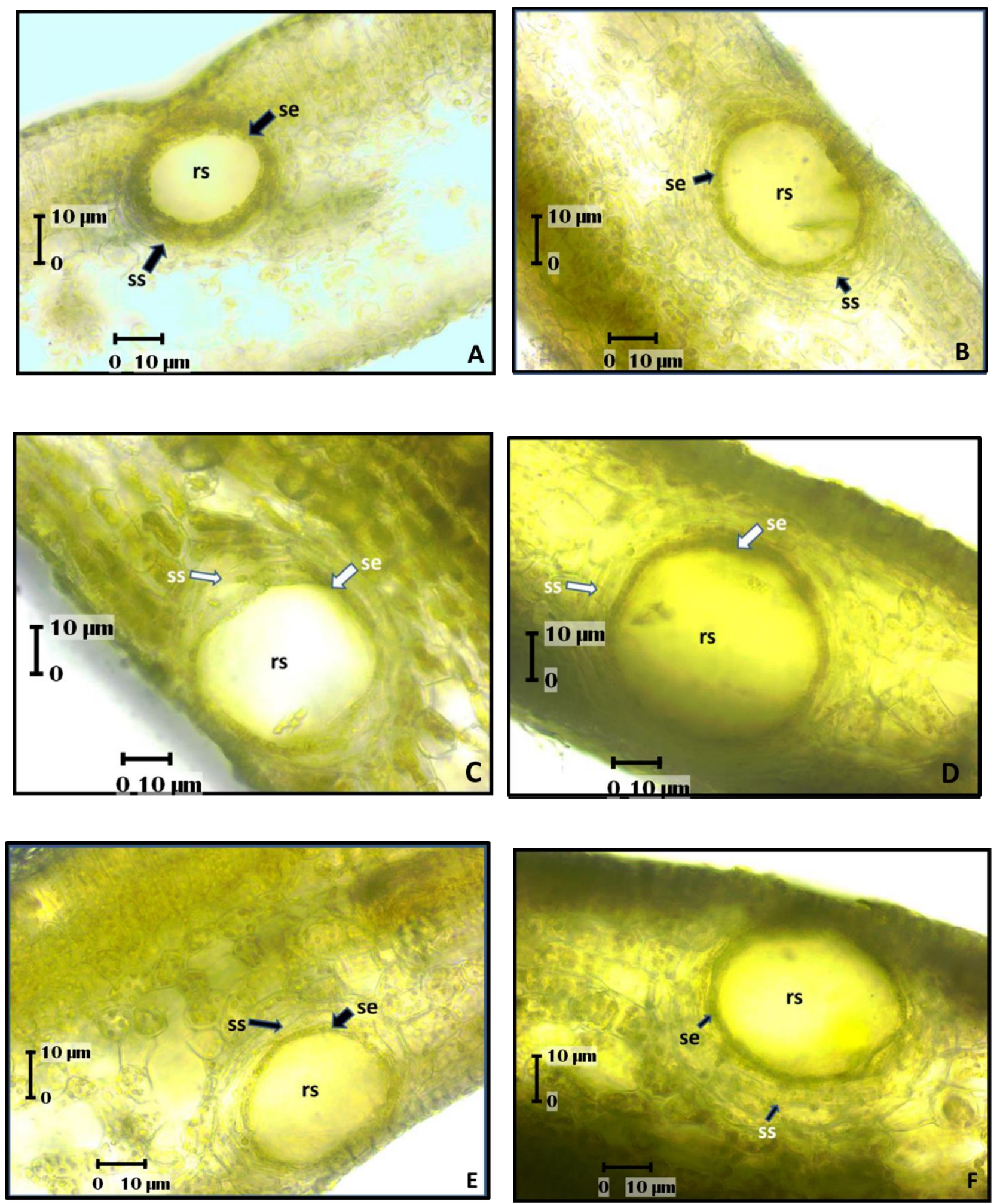

Gambar 1. Struktur sel sekresi pada daun jeruk Kalamansi (A. Halong, B. Hative Besar, C. Hukurila, D. Hutumuri, E. Kilang, dan F. Kusu-Kusu Sereh).

Keterangan: se: sel epitel, ss: sel seludang, rs: rongga sekretori. Pembesaran 400x, Bar: 10um 

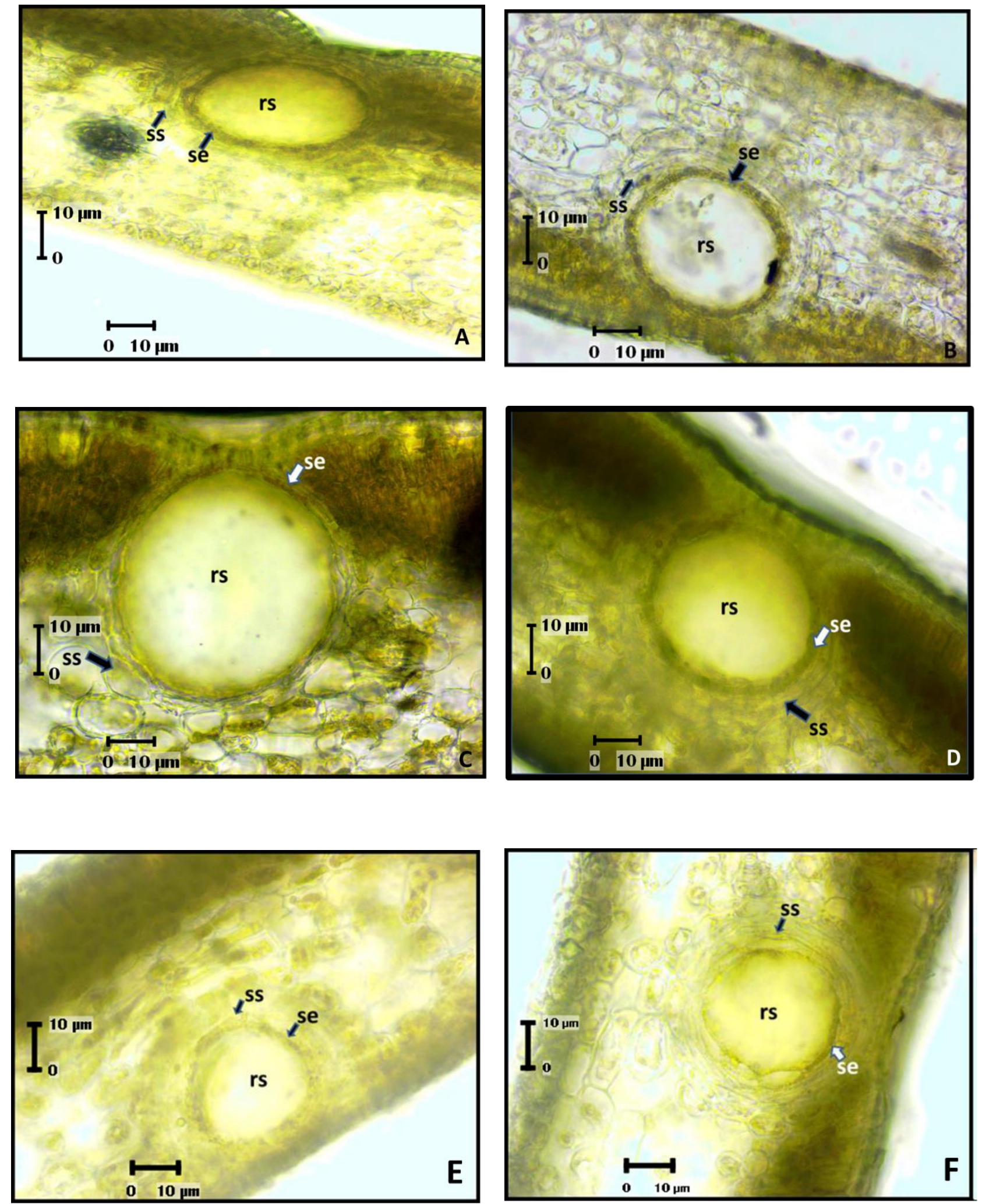

Gambar 2. Struktur sel sekresi pada daun jeruk Kalamansi (A. Latta, B. Lateri, C. Naku, D. Passo, E. Poka, dan F. Rumahtiga).

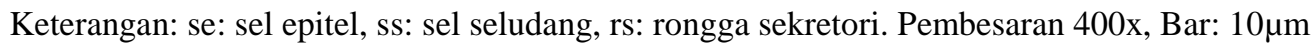




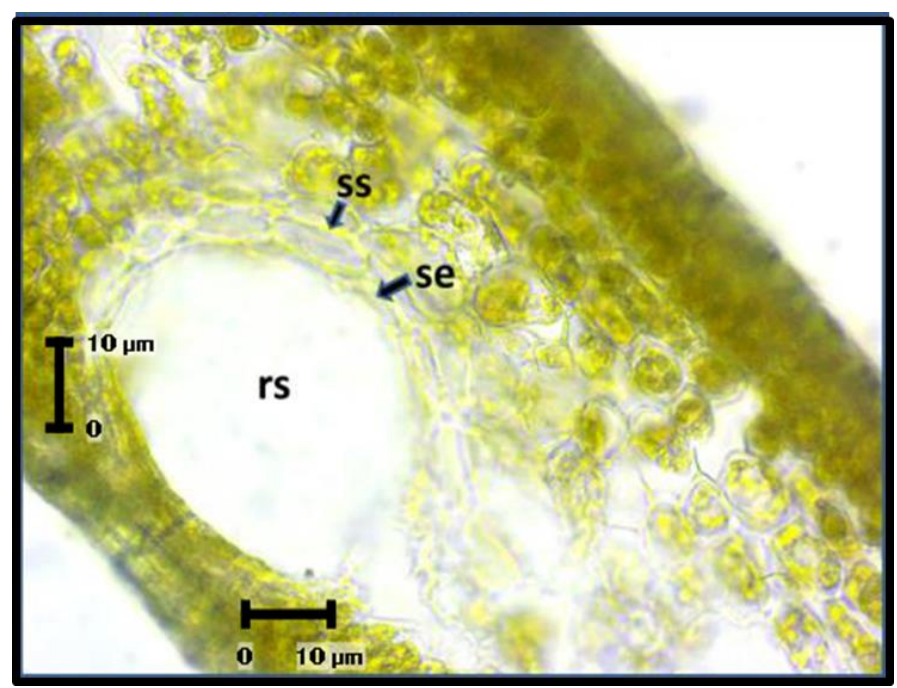

Gambar 3. Struktur sel sekresi pada daun jeruk Kalamansi dari Lokasi Desa Wayame.

Keterangan: se: sel epitel, ss: sel seludang, rs: rongga sekretori. Pembesaran 400x, Bar: 10um

Tabel 3. Ukuran sel sekresi daun jeruk Kalamansi (C. microcarpa Bunge.) pada lokasi berbeda di Pulau Ambon

\begin{tabular}{llc}
\hline No & Lokasi & Rerata ukuran diameter sel sekresi $(\mu \mathrm{m})$ \\
\hline 1. & Desa Hutumuri & $167,60 \pm 47,23$ \\
2. & Desa Wayame & $147,90 \pm 47,48$ \\
3. & Desa Kilang & $140,63 \pm 33,2$ \\
4. & Desa Latta & $132,75 \pm 38.30$ \\
5. & Desa Halong & $130,97 \pm 26,64$ \\
6. & Desa Poka & $128,94 \pm 28,81$ \\
7. & Desa Passo & $124,47 \pm 22,54$ \\
8. & Desa Naku & $116,08 \pm 36,68$ \\
9. & Desa Lateri & $115,10 \pm 23,60$ \\
10. & Kelurahan Mangga Dua (Kusu-Kusu Sereh) & $114,39 \pm 33,36$ \\
11. & Desa Hative Besar & $112,63 \pm 26.07$ \\
12. & Desa Hukurilla & $112,46 \pm 27,05$ \\
13. & Desa RumahTiga & $106,08 \pm 22,60$ \\
\hline
\end{tabular}

\section{KESIMPULAN}

Struktur sel sekresi pada jeruk terdiri dari sel epitel, sel seludang, dan rongga sekresi, (2) ukuran diameter rongga sekresi daun jeruk Kalamansi berbeda-beda pada lokasi berbeda di Pulau Ambon.dengan diameter tertinggi pada daun jeruk dari Desa Hutumuri $(167,60 \mu \mathrm{m})$ dan terendah dari Desa Rumahtiga $(106,08 \mu \mathrm{m})$.

\section{DAFTAR PUSTAKA}

ASEAN Standart. 2019. ASEAN standart for Calamansi lime. (ASEAN Stan 59 :2019)

Balitjestro: Balai Penelitian Jeruk dan tanaman Buah tropika. (2019). Balitjestro Koleksi 254 Varietas Jeruk Unggulan. https://www.suarakarya.id/detail/95293/Balitj estro-Koleksi-254-Varietas-Jeruk-Unggulan. Diakses 18 Juli 2021.

Bennici, A., \& Tani, C. (2004). Anatomical and ultrastructural study of the secretory cavity development of Citrus sinensis and Citrus limon: evaluation of schizolysigenous 
ontogeny. Flora - Morphology, Distribution, Functional Ecology of Plants, 199(6), 464$475 . \quad$ ISSN 03672530,https://doi.org/10.1078/0367253000174. (https://www.sciencedirect.com/science/articl e/pii/S0367253005701341).

Fahn, A. (1988). Secretory tissues and factors influencing their development. Phyton. 28(1), 13-26.

Fajarsari, M. (2017). Pembentukan sel sekretori pada daun dan buah jeruk nipis (Citrus aurantifolia). Prosiding Seminar Nasional Pendidikan Biologi dan Biologi Jurusan Pendidikan Biologi, Fakultas MIPA, Universitas Negeri Yogyakarta 2017, hal 5968.

Fikrinda, W. (2012).Pengaruh strangulasi single dan double terhadap perbaikankeragaan bibit jeruk pamelo (Citrus Grandis (L.) Osbeck). Departemen Agronomi Dan Hortikultura Fakultas Pertanian Institut Pertanian Bogor.

Haryanti, S. (2010). Pengaruh naungan yang berbeda terhadap jumlah stomata dan ukuran porus stomata daun Zephyranthes Rosea Lindl. Buletin Anatomi dan Fisiologi, XVIII(1), 41-48. DOI: https://doi.org/10.14710/baf.v18i1.2617

Hidayat, E.B. (1995). Anatomi Tumbuhan Berbiji. Bandung: Penerbit ITB.

Jian Liang, S., Wu, H., Lun, X., \& Lu, D.W. (2006). Secretory cavity development and its relationship with the accumulation of essential oil in fruits of Citrus medica L. var. sarcodactylis (Noot.) Swingle. Journl of Integrated Plant Biology, 48(5), 573-583. https://doi.org/10.1111/j.17447909.2006.00230.x

Nindiyawati, D.L., \& Indrayani, S. (2017). Struktur sel sekretori dan uji mikroskopi mikrokimiawi metabolit sekunder pada daun dari tujuh taksa tanaman obat antihipertensi. Jurnal Biotropika, 5(2), 59-67. DOI: http://dx.doi.org/10.21776/ub.biotropik a.2017.005.02.4

Nugroho, H.L. (2017). Struktur dan produk jaringan sekretori tumbuhan. Gadjah Mada University Press. Yogyakarta.

Purnamasari, W. (2017). Jenis-jenis sel sekretori pada tumbuhan jeruk keprok siam (Citrus nobilis). Prosiding Seminar Nasional Pendidikan Biologi dan Biologi Jurusan Pendidikan Biologi, Fakultas MIPA, Universitas Negeri Yogyakarta 2017, 83-88.
Rahangmetan, A., Sinay, H., \& Karuwal. R.L. (2021). Karakterisasi stomata daun jeruk kalamansi (Citrus microcarpa Bunge.) di Pulau Ambon. Biopendix: Jurnal Biologi, Pendidikan dan Terapan, 7(2), 180-192. https://doi.org/10.30598/biopendix vol7issue2 page 180-192.

Rahayu, E.S, \& Susanto, S. (2012). Kajian kualitas jeruk Keprok Garut (Citrus reticulata L.) pada tiga lokasi berbeda di Kabupaten Garut. Undergraduate Thesis. Departemen Agronomi Dan Hortikultura Fakultas Pertanian Institut Pertanian Bogor.

Sinay, H., Arumingtyas, E.L., Indriyani, S., \& Harijati, N. (2015). Stomata characterization of local corn cultivar wich is grown under field condition in Kisar Island Southwest Maluku Regency. Proceeding of The 5th Annual Basic Science International Conference, 5 (1), 9699.

Surlitah, S., Setiawan, B., \& Briawan, D. (2015). Perbaikan profil lipid pada perempuan dewasa kelebihan berat badan setelah intervensi sari jeruk kalamansi (Citrus microcarpa). Jurnal Gizi Pangan, 12(2), 93-100. DOI: https://doi.org/10.25182/jgp.2017.12.2. 93-100

Turner, G.W., \& Lange, B.M. (2015). Ultrastructure of grapefruit secretory cavities and immunocytochemical localization of (1)limonene synthase. International Journal of Plant Science, 176(7), 643-661. https://doi.org/10.1086/682054.

Wu, G., Terol, J., Ibanez, V., López-García, A., Pérez-Román, E., Borredá, C., Domingo, C., Tadeo, F.R., Carbonell-Caballero, J., Alonso, R., Curk, F., Du, D., Ollitrault, P., Roose, M.L., Dopazo, J., Gmitter, F.G., Rokhsar, D.S., \& Talon, M. (2018). Genomics of the origin and evolution of Citrus. Nature 554, 311-316 (2018). https://doi.org/10.1038/nature25447

Yulianti, F., Palupi, N.E., \& Agisimanto, D. (2016). Keragaman jeruk fungsional Indonesia berdasarkan karakter morfologis dan marka RAPD. Jurnal AgroBiogen, 12(2), 91-100. DOI: http://dx.doi.org/10.21082/jbio.v12n2.2 016.p91-100 